European Journal of Accounting, Auditing and Finance Research

Vol.8, No. 5, pp.1-15, May 2020

Published by ECRTD-UK

Print ISSN: 2053-4086(Print), Online ISSN: 2053-4094(Online)

\title{
ACTIVITY ACCOUNTING AND CORPORATE INVESTMENT DECISIONS AMONG SELECTED LISTED MANUFACTURING FIRMS IN NIGERIA
}

\author{
Prof. Ishola R. Akintoye, Dr. Folajimi.F Adegbie and Yisa . A. Adeniji. \\ Babcock University, Department of Accounting, Ilishan Remo, Ogun State, Nigeria
}

ABSTRACT: Over the years, corporate and institutional investors had suffered huge financial losses as a result of poor or wrong investment decisions taken on the basis of manipulated financial information. Studies have shown globally that the practice of financial report misrepresentation commonly leads to loss of credibility, integrity and confidence in accounting information and the earnings become questionable. This situation now calls for additional sources of information that would enhance the quality of corporate investment decision. This study investigated the impact of activity accounting adoption on corporate investment decisions in selected listed manufacturing companies in Nigeria. The study adopted survey research designs with a population of 54 listed manufacturing companies in Nigeria. Purposive sampling technique was used to select 510 respondents from a sample frame of 34 companies. A structured questionnaire was used to collect data validated using Cronbach Alpha with Coefficient ranging from 0.772 to 0.907 with $97.2 \%$ response rate. The data was analyzed and validated using descriptive and inferential statistics. The study found that activity accounting had significant influence on corporate investment decisions (Adj. $\left.R^{2}=0.425, R^{2}=0.429, F_{(547)}=120.747 ; p<0.001\right)$. The study concluded that activity accounting influences corporate investment decisions for different stakeholders in selected listed manufacturing companies in Nigeria. The study recommended that investors and decision makers alike should consider and monitor the organizational structure, budgetary control system and performance report in addition to the audited financial statement when embarking on corporate investment decisions.

KEYWORDS: activity accounting, corporate investment decisions, listed manufacturing firms.

\section{INTRODUCTION}

The contemporary business globally has witnessed a rapid expansion in business transactions, economic growth and development based on the investors' perceptions of investment returns and wealth maximization. Deciding on what to do towards achieving the organizational goal is a core duty of a manager. On a regular basis operating managers whether at the top, middle or low level, are usually confronted with several issues such as the nature of product to produce and sell, the methods of production, outsourcing decision, making the product in-house or sub-contracting, appropriate selling prices, market and marketing research decisions, acceptance of an extra sales order decisions and optimal allocation of available resources. Corporate investment decisions are regarded as challenging and strategic in nature. Due to the fact that different options and numerous amount of variables (both quantitative and qualitative) are involved and very few will be considered as relevant. 
European Journal of Accounting, Auditing and Finance Research

Vol.8, No. 5, pp.1-15, May 2020

Published by ECRTD-UK

Print ISSN: 2053-4086(Print), Online ISSN: 2053-4094(Online)

Corporate investment decision entails a huge outlay of capital, choosing from among at least two alternatives. From a cursory observation, corporate investment decision is yet to be given a holistic attention it deserves. Zarnowitz (1992) observed that the level of corporate investment decisions can be used to gauge the performance level of any economy from the perspectives of macro and micro. From the macro perspective in a regular business circle, investment decision account for the majority of the volatility in the Gross Domestic Product (GDP) dynamics and their magnitude serves as a significant leading indicator of economic performance. From the micro perspective, they are crucial for the growth of individual companies, increasing their efficiency by reducing units costs (Zarnowitz, 1992). The key performance indicator of any enterprise is the way and manner in which management invest the available resources. This position is premised on the fact that, appropriate investment decisions will increase the stakeholder's wealth. Such decisions may include channeling available funds to acquire equipment (acquisition of new assets or replacement decision), make in house or outsource, research and development project of new project. A decision maker must however ensure an optimal balance between an immediate cash outflow and the future cash earnings ability of the project. The research aiming at investigating the process of investment decision at the company level has generally shown that it is a multi-criteria process (Enoma \& Mustapha, 2010) taking into account numerous factors. These factors as usual include not only economic and risk factors but also the political and social environment and government regulations (Enoma \& Mustapha, 2010). Although, the effects of these factors vary significantly among individual companies (Bialowolski \& Neziak-Bialavolska, 2014) yet researchers generally ignored the impact of management accounting report such as the activity accounting statement in investment decisions.

Based on personal observation over the years, Multinational Corporation was collapsing without any prior indications. The reason for this ugly situation was not too difficult to identify. As Akintoye (2019), documented the list of financial scandals among Nigerian Companies to include: Cadbury (2006) N13.25billions, Afro-bank (2006) N6.9billions, Oceanic Bank (2010) N150billions, Bank PHB (2011) N25.7billions, Access Bank (2011) \$19millions or N6.84billions, Intercontinental Bank (2012) N400billions, and Skye Bank (2018) N126billions (Bakre, 2007; Ebhodaghe, 1996; CBN, 1997; Ifeanyi, 2011). Just recently, the federal government of the federation through the intervention of the Central Bank of Nigeria (CBN) rescued the depositor's funds, by converting the Skye Bank Plc to Polaris Bank Plc. The demise of Oceanic Bank Plc, Bank PHB Plc, Intercontinental Banks Plc, Mainstream Bank Plc, Savannah Bank Plc, Credite Bank Plc, and Enterprise Bank are still fresh in investor's memory. Currently, both the Access Bank Plc and the Diamond Bank Plc are planning to merge into one corporate entity. While the public are being told that the move is a merger decision, investors, saw the negotiation as an acquisition decision by the management of Access Bank Plc. The challenges being faced by the investors based on personal investigation is the level of reliance on the audited financial statement of listed companies in Nigeria.

Healy and Palepu (2003), opined that the corporate failure that were observed in different parts of the globe were dependent on the lack of adequacy in the information disclosure and the decision made were based on biased information where the management team purposively and wrongly misrepresent the financial information. Since those failures especially that of Worldcom, Enron 
European Journal of Accounting, Auditing and Finance Research

Vol.8, No. 5, pp.1-15, May 2020

Published by ECRTD-UK

Print ISSN: 2053-4086(Print), Online ISSN: 2053-4094(Online)

and Anderson in the USA, brought changes in the financial reporting regulation that fundamentally requires full disclosure of financial and non-financial information in order to improve the quality of information for decision making. Till date, the problems of creative accounting still persist resulting in the clamor for voluntary disclosure of financial information. Freeman, (2011); Valipour and Moradbeygi, (2011); Venazi, (2012) observed that practice of financial information manipulations to depict firms profitability has yielded distrust and apathy in most financial systems.

Many researchers concentrated mainly in the area of external factors affecting investment decisions (Azarmi \& Schmidt 2016; Efni 2017; Zheng \& Wang 2018; Pevic \& Durkin 2015, Riem, 2016) while others are interested in examining the effect of the internally generated variables on corporate investment decisions (Bistrova, Lace \& Travanaviene, 2015; Sungun, 2015). In some part of Africa, such as Kenya, Tunisia and Rwanda, most of the researchers merely concentrated on the effect of financial statement analysis on investment decision (Vestine, Mbabazize \& Kule, 2016). In Kenya, Jagongo and Mutswenje (2014) submitted that information structure and the factors in the market systematically influences individuals investment decisions as well as market outcome. This position is not different from Rwanda where (Vestine, Kule and Mbabazize, 2016) situated that financial statement analysis performs a crucial role in investment decision making and organizational performance. This has been shown to be a major force in investment decision making. While examining corporate investment decision and cash flow sensitivity, Basty (2016) submitted that investment decisions of firms with financial constraints are significantly sensitive to the availability and the level of internal funds when compared with organization without any financial constraints.

Generally, available economic literature indicates a strong relationship between corporate investment decisions and the Gross Domestic Product (GDP) of any country. This relationship also impact significantly on the economic growth and development of a nation. By implication, if there is an increase in the level of corporate investment in a particular environment, then there is the likelihood of high rate of employment, increase in national income, rise in gross domestic product (GDP) and improved quality of living standards. At the moment, Nigeria's situation is precarious due to high level of unemployment, upsurge in crime rate (such as kidnapping, armed robbery, internet fraud, yahoo plus, illegal bunkering, banditry), high rate of inflation and feeling of hopelessness among the citizenry. Invariably, all the aforementioned factors are traceable to the general decline in the level of corporate investment in the country.

However, researchers, professionals, administrators and management accountants considered activity accounting from diverse perspectives depending on their scope and the objectives being considered. In fact, there is no unified concept of activity accounting (Tran, 2017). Kermit and Barbara (1996) opined that for any organization to be successful in the adoption of activity accounting, the followings must be adhere to. First, establish responsibility centres; second; design performance measures; third; evaluate performance, and fourth; define reward system. Don and Marynne (2005) postulated that activity accounting system included four essential elements where responsibility is defined; performance measures are established; performance is measured; and individuals are rewarded. From four listed components, Gharayba, Fatena, Debi, Ma'Moon and 
European Journal of Accounting, Auditing and Finance Research

Vol.8, No. 5, pp.1-15, May 2020

Published by ECRTD-UK

Print ISSN: 2053-4086(Print), Online ISSN: 2053-4094(Online)

Nasar (2011) developed activity accounting system into seven elements. However, this study will focus on three essential elements including organizational structure, budgetary control and performance report. Each of these elements will be investigated to determine their effects on corporate investment decisions.

Adopted organizational structure may be affected by the nature of operation, size and complexities of any establishment. While small and medium size enterprises may be easier to manage effectively by few individuals, the operations of multinational corporations will be difficult to supervise by the same group of individuals (Gadave, 2017). Some writers opined that for effective operations, areas of responsibilities can be grouped into four namely: cost, revenue, profit and investment centres (Ritika, 2015; Shilpa, 2014; Zimnick, 2016). Other researchers like Atu et al, (2014); Mojgan (2012); Pajok (2014) identifies only three different areas namely: cost, profit and investment centre. This study will add to the body of knowledge by examining the impact of managers responsibility powers within the context of investment centre structure on corporate investment decision.

In Nigeria, corporate investment decisions are generally premised on financial reporting (Omokkudu \& Ibadin, 2015) with specific emphasis on investors' interest using quantitative variables such as earnings quality, accrual quality, earnings management and accounting conservatism against return on equity or earnings per share as indicated. Other studies such as Abolaji and Adeolu (2015); Ahmed and Duellman (2011); Chan-Jane, Tawei and Chae-Jung (2015); Chidiebere (2013); Ciao-Wei, Daniel, Collins, Kravet and Margenthaler (2018) used qualitative variables of relevance, faithful representations, comparability, timeliness, understandability and verifiability of financial information against companies performance and dividend policy to justify the reliance of audited financial statements as a key component of investment decisions. However the problems of corporate failure persists both in Nigeria and elsewhere, hence the need for this study. This research work therefore makes a bold attempt towards investigating the applicability of activity accounting in the field of corporate investment decisions.

\section{Objective of the study}

The main objective of this study is to examine the effect of activity accounting practices on corporate investment decisions among selected listed manufacturing firms in Nigeria. The specific objectives are to:

1. evaluate the effect of organizational structure on corporate investment decisions in selected listed manufacturing companies in Nigeria;

2. investigate the impact of budgetary control system on corporate investment decisions in selected listed manufacturing companies in Nigeria;

3. ascertain how performance report affect corporate investment decisions in selected listed manufacturing companies in Nigeria;

4. evaluate the combined effects of the three (3) components of activity accounting on corporate investment decisions among selected listed manufacturing firms in Nigeria. 
European Journal of Accounting, Auditing and Finance Research

Vol.8, No. 5, pp.1-15, May 2020

Published by ECRTD-UK

Print ISSN: 2053-4086(Print), Online ISSN: 2053-4094(Online)

\section{Research Hypotheses}

The research tested the following null hypotheses:

$\mathrm{H}_{0}$ 1: Organizational structure does not have significant effect on corporate investment decisions in selected listed manufacturing companies in Nigeria.

$\mathrm{H}_{0}$ 2: Budgetary control systems do not have significant effect on corporate investment decisions among selected listed manufacturing companies in Nigeria.

$\mathrm{H}_{0} 3$ : Performance report does not have significant impact on corporate investment decisions among selected listed manufacturing companies in Nigeria

$\mathrm{H}_{0} 4$ : Organizational structure, budgetary control system, performance report have no significant combined effect on corporate investment decisions among selected listed manufacturing firms in Nigeria.

\section{THEORETICAL REVIEW}

\section{Agency Theory}

This theory was popularized by Stephen Ross and Barry Mitnick in 1973 as documented by Mitnick (1975). The theory situates that there is a relationship based on contract between one or more people known as principals, who engage or employ another people known as agent, who provide services on behalf of the principals, who gave them power and authority to work on owners of businesses (Jensen \& Meckling, 1976). This theory opined that a company is considered as a central part of contracts between managers and shareholders. It therefore presupposes that a relationship must exist between (a) shareholders and agents (managers) or (b) between owners of the debts and stockholders represented by managers. As a result of agents and principals relationship, there must be a process of stewardship reporting that leads to decision making.

The proponents of agency theory situated that the agents should report their level of stewardship to the principals concerning the use of resources entrusted to them (Eisenhardk, 1989). So based on this submission, if divisional managers are regarded as "agent" and the central management as the "principal" then activity accounting statement will serve the stewardship needs. However, Budiarso, Mandey and Karamoy (2018), Nikkinen and Sahlstrom (2004), Williams, Ho and Carol (1999) submitted that the accounting statement presented by the operational manager should be clearly understood to all the central management or the multinational corporation.

Most scholars have adopted agency theory in explaining the rationale behind activity accounting (Arya et al., 1998; Demski \& Sappington, 1998). The theory enumerated the way accounting information can be used by owners to control both the managers and the employees (Drury, 1996) and is centered on "economic models" of decision making (Scapens, 1991) and their adoption promises increased efficiency and effectiveness of organizational performance (Baker, 2003). However, economists use agency theory to study the problems associated with motivating and controlling cooperative actions. Agency theory contended that shareholder's interest can be protected through the provision of information from the board of directors and executive management. It is therefore appropriate to posits that activity accounting and agency theory are premised on the existence of contract, this contract relies on the core relationship which exists between the agent and the principal which resulted into agency relations. 
European Journal of Accounting, Auditing and Finance Research

Vol.8, No. 5, pp.1-15, May 2020

Published by ECRTD-UK

Print ISSN: 2053-4086(Print), Online ISSN: 2053-4094(Online)

\section{Empirical Review}

Owino, et al., (2016) claimed that activity accounting is an administrative accounting method which deals with costs and revenues performance, and also used in measuring the results of all responsibility centres where performance of the managers is evaluated based on the things which are under their control. They conducted cross-sectional survey in order to find out if the concept of activity accounting is being applied among Ugandan Public Universities. Their findings clearly indicate that activity accounting follows hierarchal patterns.

Fakir, Islam and Miah (2014) investigated the impact of adopting activity accounting among the garment manufacturer in Bangladesh. The researchers adopted survey research design utilizing non-probabilistic sampling to circulate the structured questionnaire in obtaining the required primary data. Descriptive and inferential statistics revealed that the adoption of activity accounting is satisfactory in all the listed garment industries investigated.

Gadave (2017) examined the concept of activity accounting within the context of performance reporting. Using an exploratory research design, the researcher critically evaluate the concept of activity accounting by identifying the reasons for its current wide spread adoption together with the basic requirements. The researcher concluded by identifying the various responsibility centres, management support and cost control through activity accounting. However, since the study is not empirical in nature, it failed to relate activity accounting with any aspect of managerial function such as planning, controlling, decision-making or performance evaluation.

Zimnicki (2016) discussed extensively the rationale for activity accounting being regarded as an inspiration for segment reporting. Based on literature analysis, the researcher traced the historical background of activity accounting from the twentieth century to the period of centralization, decentralization and divisionalised structure. Responsibility centres was also classified into four major areas such as cost, revenue, profit and investment centres. Again, even though the analysis is detailed, it lacked empirical analysis to support any position.

Efni (2017) investigated the mediating effect of investment decisions and financing decisions on the impact of corporate value. The population adopted was the property and real estate sectors quoted on the Indonesia stock exchange for a period of nine years that is from 2001-2008 using secondary data. Based on descriptive and inferential analysis, the study observed that only the investment decisions and the company's risk are the two variables that will increase the networth of any company. On the other hand, financing decisions and dividend policy are not able to increase the market value. Even though, the study is limited to the real sector, effect of activity accounting on investment decisions was not considered.

Biswas (2017) embarked on comprehensive review of related literature on activity accounting adoption by different types of establishment. The study adopted a descriptive and exploratory design coupled with secondary data to analyse the associated benefits of implementing activity accounting system. Findings revealed a direct relationship between company activities and performance. In addition, the concept of activity accounting will facilitate effective control and 
European Journal of Accounting, Auditing and Finance Research

Vol.8, No. 5, pp.1-15, May 2020

Published by ECRTD-UK

Print ISSN: 2053-4086(Print), Online ISSN: 2053-4094(Online)

managerial decisions including corporate investment decisions. The study is however, not empirical in nature and as such not directly related to any specific establishment or environment. Owino (2017) examined the adoption of the activity accounting concept among the various universities in Uganda considering agency relation. Using cross sectional survey design comprising of both qualitative and quantitative data to examine the hypothesis. Findings revealed that agency theory is significantly related to activity accounting concept and that appropriate authorities are obtained at the departmental levels before preparing the actual budget. This research work is restricted to the academic sector of the economy and may not be directly appropriate within the private sector even in the same environment.

Tran (2017) investigated the adoption of activity accounting concept to sustainable development among the Vietnamese manufacturing firms. Based on the survey research design, with a sample size of 64 and using structured questionnaire as a research instrument to obtain relevant data from managers and head of department of textile and garment manufacturers. Based on the result provided by SPSS (22), findings revealed that the adoption of activity accounting is at different stages and not necessarily at the same level. The study however, did not relate responsibility accounting with the corporate investment decision.

Rani and Rani (2015) stated that the size of organization determines whether the structure of it should be centralized or decentralized along with defining activity accounting system, which is necessary in terms of delegation of responsibilities and authorities where the managers are made to be responsible for planning and controlling the business activities. They also added that, comparing each responsibility centre's standard data with actual data, organization's performance result can be either favourable or unfavourable where the greater actual data than that of standard, the favourable the result would be, and vice- versa.

Akembor and Nwaiwu (2013) conducted a research where activity accounting is a system with which performance of different segments are evaluated. For attaining their goal, they developed research questions, formulated hypothesize and reviewed related literature. As research instrument they made questionnaire which population consists a sample of 32 accountants in Rivers State of the manufacturing industry. The collected data was analyzed using descriptive statistics and the hypotheses were based on chi-square test. The study evaluated that the activity accounting is not at all suitable for segment performance on specific manufacturing firms. The researcher suggested that to take the challenge facing activity accounting, adequate effort would be needed by organizational executives. They suggest that effectiveness can be achieved by developing market capitalization of those companies, providing enough and skilled manpower and ensuring current data collection about cost, profit investment of the Nigerian company.

\section{Justification for the Study}

Generally, previous literature provides evidence that corporate investment decisions are universally influenced by various factors among which are corporate risk and dividend (Efni, 2017), knowledge spillover level (Zheng \& Wang, 2018), financial statement analysis (Anaja \& Onoja 2015, Vestine, Kule\& Mbabazize, 2016)stock market valuation (Azarmi \& Schmidt, 2016), earnings management (Julio \& Yook, 2016), political uncertainty (Riem, 2016), cashflow 
Print ISSN: 2053-4086(Print), Online ISSN: 2053-4094(Online)

sensitivity (Basty, 2016), interest rate (Ibi, Offiong \& Udofia, 2015), corporate governance (Bistrova, Lace \& Travonaviene, 2015), survival and replacement of worn-out assets (Pevic \& Durkin, 2015), macroeconomics and law-related factors (Bialowalski, \& Weziak-Bialowolski, 2014), capital structure (Arafat, Warokka \& Suryasaputra, 2014) but not on activity accounting. Literature that dealt with activity accounting were only focusing on its effect on sustainable development (Tran, 2017), segment reporting (Zimnicki, 2016), organizational structure (Mojgan, 2012; Ritika, 2015), segment performance (Akembor \& Nwaiwu, 2013), and profit planning (Ocansey \& Enahoro, 2012). Thus, this study hopes to expand the frontier of knowledge by adopting quantitative measures in evaluating the effect of activity accounting on corporate investment decisions among selected listed manufacturing companies in Nigeria.

\section{Operationalization of Variables}

For the use of primary data, the following models functions were developed

$\mathrm{Y}=f(\mathrm{x})$

$\mathrm{y}=$ Dependent variable

$\mathrm{x}=$ Independent variable

$\mathrm{y}=$ Corporate Investment Decisions (CID)

$\mathrm{x}=$ Activity Accounting (AA)

$\therefore \mathrm{CID}=f(\mathrm{AA})$

$\mathrm{X}=\left(\mathrm{x}_{1}, \mathrm{x}_{2}\right.$ and $\left.\mathrm{x}_{3}\right)$

$\mathrm{x}_{1}=$ ORS $=$ Organizational structure

$\mathrm{x}_{2}=\mathrm{BUD}=$ Budgetary Control System

$\mathrm{x}_{3}=\quad \mathrm{PRT}=$ Performance Report

$\mathrm{y}=$ Corporate investment decisions

From these formulated variables and sub-variables formulated as the proxies to measure the major variables, the study set the following functional relationships to test the research objectives using primary data.

Functional Relationship

$\mathrm{CID}=f(\mathrm{ORS})-$ Equation 1

$\mathrm{CID}=f(\mathrm{BUD})-$ Equation 2

$\mathrm{CID}=f(\mathrm{PRT})-$ Equation 3

$\mathrm{CID}=f(\mathrm{ORS}, \mathrm{BUD}, \mathrm{PRT})-$ Equation 4

\section{METHODOLOGY}

The study adopted survey research design to gather data. Survey method was adopted to collect primary data from the respondents. The study focused on manufacturing organizations registered and quoted by the Nigeria stock exchange (NSE). From the total population of fifty four (54) quoted manufacturing firms, a sample of thirty four (34) firms were purposively selected for data collection spread across five (5) industries comprising Conglomerates, consumer goods, health care, industrial goods and natural resources. The sampling frame comprises of the top management, members of the accounting and finance division together with respondents from the firm of external auditors. The study used quantitative approach by measuring respondents' view on a graduated scale for statistical analysis in order to have a reasonable accurate measurement of 
European Journal of Accounting, Auditing and Finance Research

Vol.8, No. 5, pp.1-15, May 2020

Published by ECRTD-UK

Print ISSN: 2053-4086(Print), Online ISSN: 2053-4094(Online)

the constructs rather than using observation. Data were collected mainly from primary sources and analyzed using descriptive and inferential statistics.

\section{RESULTS AND DISCUSSION OF FINDINGS}

\section{Hypothesis One}

Ho $^{1}$ : Organizational structure has no significant effect on corporate investment decision in listed manufacturing companies in Nigeria

Table 4.1: Correlation coefficient between organizational structure and corporate investment decision in listed manufacturing companies in Nigeria

\begin{tabular}{|l|ll|l|l|l|l|}
\hline Variables & Mean & $\begin{array}{l}\text { Std. } \\
\text { Deviation }\end{array}$ & N & r & p & Remark \\
\hline Corporate Investment Decision (\%) & 76.55 & 14.88 & 486 & 0.60 & $<0.001$ & Sig. \\
\hline Organizational Structure (\%) & 78.16 & 13.26 & & & & \\
\hline
\end{tabular}

Table 4.2: Regression analysis of the relationship between organizational structure and corporate investment decision in listed manufacturing companies in Nigeria

\begin{tabular}{|l|l|l|l|l|l|l|}
\hline Model & B & $\begin{array}{l}\text { Std. } \\
\text { Error }\end{array}$ & $\mathbf{T}$ & Sig. & $\mathbf{R}^{\mathbf{2}}$ & $\mathbf{F}_{\mathbf{1 , 4 8 4}}=272.978 ;$ \\
\hline Constant) & 23.887 & 3.233 & 7.389 & $<0.001$ & 0.361 & $\mathrm{p}<0.001$ \\
\hline Organizational Structure & 0.674 & .041 & 16.522 & $<0.001$ & & \\
\hline
\end{tabular}

The regression model of the effect of organizational structure on corporate investment decision in listed manufacturing companies in Nigeria is given as:

\section{Corporate Investment Decision $=23.887+0.674 *$ Organizational Structure Hypothesis Two}

$\mathbf{H o}^{2}$ : Budgetary Control system has no significant effect on corporate investment decision in listed manufacturing companies in Nigeria

Table 4.3: Correlation coefficient between budgetary control system corporate investment decision in listed manufacturing companies in Nigeria

\begin{tabular}{|l|l|l|l|l|l|l|}
\hline Variables & Mean & $\begin{array}{l}\text { Std. } \\
\text { Deviation }\end{array}$ & N & r & p & Remark \\
\hline Corporate Investment Decision (\%) & 76.55 & 14.88 & 486 & 0.54 & $<0.001$ & Sig. \\
\hline Budgetary control system (\%) & 76.89 & 12.91 & & & & \\
\hline
\end{tabular}

Table 4.4: Regression analysis of the relationship between budgetary control system among and corporate investment decision in listed manufacturing companies in Nigeria

\begin{tabular}{|l|l|l|l|l|l|l|}
\hline & & $\begin{array}{l}\text { Std. } \\
\text { Modror }\end{array}$ & T & Sig. & $\mathbf{R}^{2}$ & F 1,484 = 194.315; \\
\hline Constant & 29.052 & 3.454 & 8.410 & $<0.001$ & 0.287 & $\mathrm{p}<0.001$ \\
\hline Budgetary Control & 0.618 & .044 & 13.940 & $<0.001$ & & \\
\hline
\end{tabular}


European Journal of Accounting, Auditing and Finance Research

Vol.8, No. 5, pp.1-15, May 2020

Published by ECRTD-UK

Print ISSN: 2053-4086(Print), Online ISSN: 2053-4094(Online)

\section{Corporate Investment Decision $=29.052+0.618 *$ Budgetary control}

\section{Hypothesis Three}

$\mathbf{H}_{0}{ }^{3}$ : Performance report has no significant effect on corporate investment decision in listed manufacturing companies in Nigeria

Table 4.5: Correlation coefficient between performance report and corporate investment decision in listed manufacturing companies in Nigeria

\begin{tabular}{|l|l|l|l|l|l|l|}
\hline Variables & Mean & $\begin{array}{l}\text { Std. } \\
\text { Deviation }\end{array}$ & N & r & p & Remark \\
\hline Corporate Investment Decision (\%) & 76.55 & 14.88 & 486 & 0.55 & $<0.001$ & Sig. \\
\hline Performance Report (\%) & 76.32 & 13.14 & & \\
\hline
\end{tabular}

Table 4.6: $\quad$ Regression analysis of the relationship between performance report and corporate investment decision in listed manufacturing companies in Nigeria

\begin{tabular}{|l|l|l|l|l|l|l|}
\hline & Std. & & & & \\
Model & B & Error & T & Sig. & $\mathbf{R}^{\mathbf{2}}$ & F 1,484=207.346; \\
\hline Constant) & 29.227 & 3.335 & 8.765 & $<0.001$ & \multirow{2}{*}{0.300} & $\mathrm{p}<0.001$ \\
\hline Performance Report & 0.620 & .043 & 14.400 & $<0.001$ & & \\
\hline
\end{tabular}

Corporate Investment Decision $=\mathbf{2 9 . 2 2 7}+\mathbf{0 . 6 2 0} *$ Performance Report

Table 4.7: Descriptive Statistics of all variables

\begin{tabular}{|l|l|l|}
\hline Variables & Mean & Std. Deviation \\
\hline Corporate Investment Decision (CID) & 76.61 & 14.90 \\
\hline Organizational Structure (ORS) & 78.18 & 13.27 \\
\hline Budgetary Control (BUD) & 76.94 & 12.92 \\
\hline Performance Report (PRT) & 76.39 & 13.14 \\
\hline
\end{tabular}

Table 4.7 shows that the mean corporate investment decisions rating is $76.55 \%(\mathrm{sd}=14.88 \%)$, organizational structure is $78.18 \%(\mathrm{sd}=13.27 \%)$, budgetary control is $76.94 \%(\mathrm{sd}=12.92 \%)$ and the mean performance report rating was $76.39 \%(\mathrm{sd}=13.14 \%)$.

\section{Hypothesis Four}

Ho4: Organizational structure, budgetary control and performance report have no significant combined effect on corporate investment decision in listed manufacturing companies in Nigeria

Table 4.8: Regression model of the combined effect of selected independent variables on corporate investment decision in listed manufacturing companies in Nigeria

\begin{tabular}{|c|c|c|c|c|}
\hline Model & B & Std. Error & $\mathbf{T}$ & Sig. \\
\hline Constant & 10.918 & 3.514 & 3.107 & 0.002 \\
\hline Organizational Structure (ORS) & 0.413 & 0.053 & 7.861 & $<0.001$ \\
\hline Budgetary Control (BUD) & 0.228 & 0.056 & 4.096 & $<0.001$ \\
\hline Performance Report (PRT) & 0.207 & 0.057 & 3.605 & $<0.001$ \\
\hline
\end{tabular}


European Journal of Accounting, Auditing and Finance Research

Vol.8, No. 5, pp.1-15, May 2020

Published by ECRTD-UK

Print ISSN: 2053-4086(Print), Online ISSN: 2053-4094(Online)

The regression model of the combined effect of all independent variables on corporate investment decision in listed manufacturing companies in Nigeria is given as:

CID $=10.819+0.413 *$ ORS $+0.228 * B U D+0.207 *$ PRT

The model shows that an improvement in organizational structure, budgetary control, and performance report relatively increase corporate investment decision of listed manufacturing companies in Nigeria by $\mathbf{0 . 4 1 3 \%}, \mathbf{0 . 2 2 8 \%}$ and $\mathbf{0 . 2 0 7 \%}$ respectively. Their relative effect shows that organizational structure, budgetary control system and performance report are all significant (ORS: $\beta_{1}=0.413, t_{(480)}=7.861 ; p<0.05 ; \quad B U D: \beta_{2}=0.228, t_{(480)}=4.096 ; p<0.05 ;$ PRT: $\beta_{3}=$ $\mathbf{0 . 2 0 7}, \mathbf{t}(\mathbf{4 8 0})=3.605 ; \mathbf{p}<\mathbf{0 . 0 5})$. The overall effect of all three independent variables measured by the F-statistics shows that all the variables have a significant combined effect on corporate investment decision in listed manufacturing companies in Nigeria $\left(\mathbf{F}_{3,483}=120.747 ; \mathbf{p}<\mathbf{0 . 0 5}\right)$. The adjusted coefficient of determination reveals that all the variables combined explain only $42.5 \%$ of the total variability in corporate investment in listed manufacturing companies in Nigeria (Adj. $\mathbf{R}^{2}=\mathbf{0 . 4 2 5}$ ).

Therefore, the null hypothesis is rejected and it is concluded that organizational structure, budgetary control and performance report combined have significant effect on corporate investment decision in listed manufacturing companies in Nigeria.

\section{DISCUSSION OF FINDINGS}

The relationship between activity accounting and corporate investment decisions were found to the very high and significant. Similarly, the individual components o activity accounting was generally found to be highly correlated with the corporate investment decisions among listed manufacturing companies in Nigeria. On a general note, activity accounting had significant effect on corporate investment decisions among the manufacturing firms $\left(\operatorname{Adj} R^{2}=0.425 ; F_{(5474)}=\right.$ 120.747, $p<0.001$ ). Analysis established the fact that on individual basis, each component of activity accounting also had significant effect on corporate investment decisions. There is a strong positive and significant relationship between corporate investment decision and organizational structure. The implication of this statistics, is that a well defined organizational structure will enhance the quality of corporate investment decisions $\left(\operatorname{Adj} R^{2}=0.361 . F_{1484}=272.978, p<0.001\right)$. Budgetary control revealed a strong, positive and significant relationship with the corporate investment decisions $\left(R^{2}=0.287, F_{1484}=194.315 ; p<0.001\right)$. Further analysis also indicated that a strong, positive and significant relationship exist between corporate investment decisions and performance reports among listed manufacturing companies in Nigeria (Adj. $R^{2}=0.300, F_{1484}$, 207.346; $p=0.001$ ).

\section{CONCLUSION AND RECOMMENDATIONS}

The study examined the effect of responsibility accounting on corporate investment decisions in listed manufacturing companies in Nigeria. The findings from the study provide relevant empirical evidence by showing that organizational structure, budgetary control and performance report have significant effect on corporate investment decisions. The implications of the activity accounting adoption on corporate investment decisions were given statistical and empirical fundamentals considered useful for policy and strategy formulations. The study concluded that: 
European Journal of Accounting, Auditing and Finance Research

Vol.8, No. 5, pp.1-15, May 2020

Published by ECRTD-UK

Print ISSN: 2053-4086(Print), Online ISSN: 2053-4094(Online)

i) Organizational structure has strong, significant and positive effect on corporate investment decisions in listed manufacturing companies in Nigeria;

ii) Budgetary control has a strong, positive and significant influence on corporate investment decisions among listed manufacturing companies in Nigeria.

iii) Performance report exerts a strong, positive and significant effect on corporate investment decisions among listed manufacturing companies in Nigeria.

iv) Activity accounting has a significant strong and positive influence on corporate investment decisions among listed manufacturing companies in Nigeria.

Based on the aforementioned, the study therefore recommend that investors and decision makers alike should consider and monitor the effectiveness of organizational structure, budgetary control system and performance report as a premise for investment decision making rather than just focusing on the audited financial statement when embarking on corporate investment decisions.

\section{REFERENCES}

Abolaji, O. B. \& Adeolu, O. O. (2015). Perceived effects of international financial reporting standards (IFRS) adoption on quality financial reporting of quoted companies in Nigeria. Research Journal of Finance and Accounting, 6(23), 1-8.

Ahmed, A. S. \& Duellman, S. (2011). Evidence on the role of accounting conservatism in monitoring managers' investment decisions. Accounting and Finance, 51(3), 609-633.

Ajagbe M.A. (2007). The Impact of Strategic Planning on Effectiveness of Marketing Operations: Case of NEPA. An Unpublished MBA Thesis Submitted to the Graduate School, Ambrose Ali University, Ekpoma, Nigeria.

Akembor, C. O. \& Nwaiwu, J. N (2013). The effectiveness of responsibility accounting in evaluating segment performance of manufacturing firms. KASU Journal of Accounting Research and Practice. 2(2), 103-112.

Akintoye, I.R. (2019). Accounting: A Mismanaged Concept Requiring Urgent Re-definition. $28^{\text {th }}$ Inaugural Lecture, Babcock University.

Arya, A., Glover, J., \& Radhakrishman, S. (1998). The Controllability Principle in Responsibility Accounting. Another look: Retrieved from http://wenku.baidu.com/view

Atu, O. O. K., Ogbeide, E., Agbo, I. S. \& Ozele, C. E. (2014). Responsibility Accounting: An Overview. IOSR Journal of Business and Management. 16(1), 73-79.

Azarmi, T. \& Schmidt (2016). Determinants of Corporate Investments: Theory and Evidence on the Investment Effect of Corporate Taxes. Accounting and Business Research, 46(7), 731759.

Baker, C.R. (2003). Theoretical Approaches to MICS, in proceeding of the Annual Conference of the Administrative Sciences of Association of Canada Critical Accounting Research Track, edited by Normal Macintosh, 25(3), 283-299.

Bakre, O.M. (2007). The Unethical Practices of Accountants and Auditors and the Compromising Stance of Professional Bodies in the Corporate Nigeria: Accounting Forum, 31(3), 277303.

Basty, N. (2016). Corporate investment and cashflow sensitivity: Evidence from a Jasmin revolution period in Tunisia market. Asian economic and financial review. 6(11), 634-646. 
European Journal of Accounting, Auditing and Finance Research

Vol.8, No. 5, pp.1-15, May 2020

Published by ECRTD-UK

Print ISSN: 2053-4086(Print), Online ISSN: 2053-4094(Online)

Bialowolski, P. \& Weziak-Bialowolska, D. (2014).External factors affecting investment decisions of companies. Economics: The Open-Access, Open-Assessment E-Journal, 8 (1),1-21.

Bistrova, J., Lace, N. \& Tvaronaviciene, M. (2015).Corporate governance as a factor for investment decision making on CEE equity markets. The 15th world multi-conference on systemics, cybernetics and informatics proceedings. 1, 59-64.

Biswas, T. (2017). Responsibility Accounting: A review of related literature. International Journal of Multidisciplinary Research and Development. 4(8), 202-206.

Budiarso, N. S., Mandey, S. L. \& Karamoy, H. (2018). Testing of agency and stewardship theories on financial accountability in Sulawesi region, Indonesia. International Journal of Finance and Accounting, 7(1), 13-18.

CBN (1997). Financial Sector Distress in CBN Briefs. Research Department, 97(1), 12.

Chan-Jane, L., Tawei, W. \& Chae-Jung, P. (2015).Financial reporting quality and investment decisions for family firms. Asia Pacific Journal of Management, 1(1), 1-34.

Chidiebere, M. E. (2013). Reliance on published financial statements and investment decision making in the Nigeria banking sector. European Journal of Accounting Auditing and Finance Research, 1(4), 67-82.

Ciao-Wei, C., Collings, W.D., Kravet, T. D. \& Mergenthaler, R. D. (2018).Financial statement comparability and the efficiency of acquisition decisions. Contemporary Accounting Research, 34(4), 1299-1310.

Demiski, J.S. \& Sappington, D.E. (1989). Hierarchal Structure and Responsibility Accounting. Journal of Accounting Research. 27(1), 40-51.

Don, R.H., \& Marynne, M.M. (2005).Management Accounting. McGraw-Hill Companies. Inc.

Drury, C. (1996). Management and Cost Accounting ( $4^{\text {th }}$ Edition) International Thomson Business Press London.

Ebhodaghe, J.U. (1996). Distress Management and Prevention Strategies for the Nigerian Banking System. NDIC Quarterly, 6(3), 19-36.

Efni, Y. (2017). The mediating effect of investment decisions and financing decisions on the effect of corporate risk and dividend policy against corporate value. Investment Management and Financial Innovations. 14(2), 27-37.

Eisenhardt, K.M. (1989). Agency Theory: An Assessment and Review. The Academy of Management Review, 14(1), 57-74.

Enoma, A. \& Mustapha, I. (2010).Factor analysis of investment decision in Nigerian insurance companies. Interdisciplinary Journal of Contemporary Research in Business, 2(8), 108120.

Fakir, A. N. M. A., Islam, M. Z \& Miah M. S. (2014). The use of responsibility accounting in garments industry in Bangladesh. Journal of business studies. 1(2), 1-15.

Freeman, R. E (2011). Some thoughts on the development of stakeholder theory. In R. Phillips (Ed.) Stakeholder Theory: 25 Years Later, 212-233. Cheltenham, UK: Edward Elgar Publishing.

Gadave, B. R. (2017). Glimpses on Responsibility Accounting and Reporting. Imperial Journal of Interdisciplinary Research (IJIR). 3(2); 22-28

Gharayba, Fatena, Debi, Ma'Moon, \& Nasar, A. (2011). The extent of applying the elements of responsibility accounting in the industrial shareholding companies and its effect on the 
European Journal of Accounting, Auditing and Finance Research

Vol.8, No. 5, pp.1-15, May 2020

Published by ECRTD-UK

Print ISSN: 2053-4086(Print), Online ISSN: 2053-4094(Online)

company's profitability and operational efficiency. Administrative Sciences. 38(1), 219234.

Gimenez P.A.F. (2000). The Benefits of a Coherent Strategy for Innovation and Corporate Change: A Study Applying Miles and Snow's Model in the Context of Small Firms Strategy and Innovation in SMEs. 9(4), 235-244.

Greenberg, J. (2011). Behavior in Organizations (10 ${ }^{\text {th }}$ Edition) Upper Saddle River, NE Prentice Hall.

Healy, P. M \& Palepu, G. K. (2003).The fall on Enron. Journal of Economic Perspectives, 17(2), 3-26.

Ifeanyi, D. (2011). "Corporate Governance and Bank Failure in Nigeria: Issues, Challenges and Opportunities". Research Journal of Finance and Accounting, 2(2), 1-18.

Jagongo, A. \& Mutswenje, V. S. (2014). A survey of the factors influencing investment decisions: The case of individual investors at the NSE. International Journal of Humanities and Social Science. 4, 92-102.

Jensen, M. C. \& Meckling, W. H. (1976). Theory of the firm: Managerial behavior, agency costs, and ownership structure. Journal of Financial Economics, 3(4), 305-360.

Kermit, D.L. and Barbara, C. (1996). Fundamental Accounting Principles (14 ${ }^{\text {th }}$ Edition) Chicago, IL: Richard Irwin Time Mirror Higher Education Group.

Maduenyi, S., Oke, A. O. \& Ajagbe, M. A. (2015).Impact of organizational structure on organizational performance. International conference on African development issues: social and economic models for development track.354-358.

Mintzberg H. (2009). Tracking Strategies: Toward a general theory of strategy formation. New York, NY Oxford University Press.

Mitnick, B. M. (1975). The theory of agency: The policing paradox and regulatory behavior. Public Choice (Winter), 24(1), 27-42.

Mojgan, S. (2012).Examining the role of responsibility accounting in organizational structure. American Academic \& Scholarly Research Journal. 4(5), 12-22

Nikkinen, J. \& Sahstrom, P. (2004). Does agency theory provide a general framework for audit pricing? International Journal of Auditing, 8(3), 253-262.

Omokhudu, O. O. \& Ibadin, O. P. (2015). The value relevance of accounting information: evidence from Nigeria. International Journal of Finance and Accounting, 5(3), 165-176.

Pajrok, A. (2014). Responsible accounting in the hospitality industry. Journal of Education Culture and Society. 1(2); 53-60.

Parnell J. \& Wright, P. (1993). Generic Strategy and Performance: An Empirical Test of the Miles and Snow Typology British Journal of Management, 1(1); 29-36.

Pevic, M. \& Durkin, J. (2015). Determinants of investment decisions in a crisis: perspective of Croatians small firms. Management, 20(1), 115-133.

Rani, R. \& Rani, M. (2015).The role of responsibility accounting in organizational structure, international journal of science, technology and management. 41(1), 185-190.

Riem, M. (2016).Corporate investment decisions under political uncertainty. Ifo Working Paper, No. 221, Leibniz Institute for Economic Research at the University of Munich, Munich.

Ritika, M. R. (2015). The role of responsibility accounting in organizational structure. International Journal of Science, Technology and Management, 4(1), 185-190. 
European Journal of Accounting, Auditing and Finance Research

Vol.8, No. 5, pp.1-15, May 2020

Published by ECRTD-UK

Print ISSN: 2053-4086(Print), Online ISSN: 2053-4094(Online)

Shilpa, G. (2014). Responsibility Accounting practices in India. 2nd International Conference on Multidisciplinary Research \& Practice. 3(1), 373-378.

Sungun, G. (2015). Capital investment decisions in small and medium sized enterprises in Turkey. European Journal of Accounting, Auditing and Finance Research. 3(1), 46-55.

Thomas S.A. \& Ramaswamy R. (1996). Matching Managers to Strategy: Further Tests of Miles and Snow Typology British Journal Management, 7(1), 247-261.

Tran, T. T. (2017). Application Responsibility Accounting to Sustainable Development in Vietnam Manufacturers: An Empirical Study. Economics World. 5(6), 573-583.

Valipour, H \& Moradbeygi, M. (2011). Corporate debt financing and earning quality. Journal of Applied finance \& Banking, 1(3), 139- 157

Venazi, D. (2012). Financial performance measures and value creation. Journal of Art 1(1), 9 13.

Vestine, M., Kule, J. W., \& Mbabazize, M. (2016).Effect of financial statement analysis on investment decision making. A case of bank of Kigali. European Journal of Business and Social Sciences. 1 (5), 279-303.

Williams, S.M., Ho, W.P., \& Carol, A. (1999). Corporate Social Disclosures by Listed Companies on their Web-sites: AN International Comparison. The International Journal of Accounting, Elsevier, 34(3), 389-419.

Zarnowitz, V. (1992).Rational Expectations and Macroeconomic Forecasts. In Zarnowitz V. Ied.), Business Cycles: Theory, History, Indicators, and Forecasting, 1(1), 462-491)

Zheng, J. \& Wang, Y. (2018).Research on Knowledge Resources Investment Decisions in Cooperated New Product Development. Journal of Service Science and Management, 11(1), 101-115.

Zimnicki, T. (2016).Responsibility accounting inspiration for segment reporting. Copernican Journal of Finance \& Accounting, 5(2), 219-232. 